\title{
Overall Scenario and Assessment of the Factors for Price Volatility of Cumin in Rajasthan
}

\author{
Priyanka Solanki* \\ Agri Business Management, College of Horticulture and Forestry, \\ Jhalawar (Agriculture University, Kota), India \\ *Corresponding author
}

\section{A B S T R A C T}

Keywords

Cumin, Price,

Perception

Article Info

Accepted:

20 June 2019

Available Online:

10 July 2019

The objective of this paper is to study overall scenario of the cumin at the national and international level as well as to analyze the perception of traders' on the major factors influencing cumin prices in the spot market. India contributes about 70 per cent of world cumin production followed by Syria, Iran and other countries. India accounts for 73 per cent of the Global trade. For analysing the perception of traders regarding factors affecting prices of the Cumin twenty factors have been considered in this study. The study shows that higher export order; quality and grades of the cumin; weather; higher production of cumin; higher demand from processor, stockiest as well as retailers and futures trading are the major factors according to the traders' perception. However, increase in production cost; population increase as well as income growth of consumer were not perceived influencing factors for cumin prices.

\section{Introduction}

Cumin is also known as jeera/zeera or comino. Its botanical name is Cuminum cyminum $\mathrm{L}$. and it belongs to Apiaceae family. It is the second most popular spice in the world after black pepper. Cumin was known to the Egyptians 5000 years ago and it was found in the pyramids. It is extensively cultivated in the Mediterranean region of Europe and in India. Though cumin is a native of Egypt but now it is mostly produced in India. Cumin is generally cultivated in the hot and humid climate that is provided by the regions in North Africa, southern parts of the North American continent and southern Asia. The cumin crop can be produced on almost all soil types but well-drained, fertile sandy soil type suits best for this crop. It needs a minimum of 3 to 4 months of duration after which it is harvested. Cumin plant has a good tap root system that makes it a drought resistant plant (CRN India).

In India the cumin plant is grown as a rabi crop i.e. it is sown in the winters in the months 
of October to December and is harvested in the months of February, March and April. In other cumin cultivating countries in the Middle East, the crop is planted in the months of April and is harvested in the months of August and September. The plant becomes mature and ready to harvest when it turns yellowish brown.

After the crop gets harvested, the cumin seeds are cleaned up through the winnowing process. It thrives well between $9^{\circ}$ to $26^{\circ} \mathrm{C}$ and annual rainfall of 30 to 270 centimeters. Crop duration is 110-120 days depending on the variety. Unlike other tropical plants, it requires relatively less water and rainfall during the harvesting period because it is unfavourable for the seed quality.

Commercially, cumin is available in whole seeds and more commonly in grounded form. Cumin's aromatic, nutty-flavoured seeds come in three colours: amber (the most widely available), white and black (both found in Asian markets). White cumin seed is interchangeable with amber, but the black seed has a more complex, peppery flavour.

Various studies have been conducted to study factors affecting agricultural commodities prices.Gallagher identified both short as well as long run factors that are affecting agricultural commodities prices. According to his studies weaknesses on the supply affects the prices of the commodities. He identified factors like short term stocking of the commodity as well as stochastic shocks like drought as short run factors that is affecting the prices where as long -term factors also play important role on the supply side i.e. falling agricultural productivity. World production of rice and wheat has barely increased in the past 10 years, and agricultural productivity has severely slowed in several key producing countries. So, it's an important factor that affects prices in long run.
Agricultural commodity prices respond rapidly to actual and anticipated changes in supply and demand conditions. Because demand and supply of farm products, particularly basic grains, are relatively priceinelastic. The weather can produce large fluctuations in farm production. A short-term supply related to particular season, response to a price rise can be very limited during periods of low stock holdings, but in the longer run expanded acreage and more intensive cultivation practices can work to increase supplies. When prices fall, the cost of storage relative to the price decline helps producers determine if commodities that can be stored should be withheld from the market. Similarly, demand depends on several factors, including number and availability of substitutes, importance of the commodity as measured by its share of consumers' budgetary expenditures, and strength of consumers' tastes and preferences. Increasing demand for grains for industrial use, whether from processing industries or from rapidly expanding industrial hog and poultry operations, further reinforces the general price inelasticity of demand for many agricultural commodities. In general, elasticity of demand and supply for agricultural products are both low but not uniform and consistent across commodities (Schnepf, 1999).

Traders' perception about factors affecting prices holds great importance as they are always working on taking advantage of changes in prices. They are well aware about the factors affecting prices of commodities in the market. This study was done considering traders' perception important to understand the factors affecting prices of cumin.

\section{Materials and Methods}

Rajasthan is one of the major state producing more than 40 per cent of cumin and was convenient for researcher also to collect data 
from Rajasthan therefore was selected for collecting primary data about traders' perception. The selection of mandis was done to interview the traders and mandi officials to identify major factors responsible for price variation in major crops of Rajasthan. The mandi was purposely selected on the basis of highest arrivals of the cumin in mandi. Primary data were collected using detailed survey of traders by the structured questionnaire for identifying the major factors responsible for price determination in selected Nagaur AMPC mandi.

Multistage sampling technique was used in selection of the traders. At the first stage, purposive sampling was used for selecting APMC mandi based on highest arrivals of the commodity. At the second stage, 50 traders were selected randomly from selected Nagaur mandi from the list provided by the mandi officials.

\section{Results and Discussion}

India has ever been the world spice home and has always been renowned for the best and expensive variety of spices that are produced in the country. The similar reputation is repeated in the case of cumin seeds. Being the largest producer, consumer and exporter of cumin in the world, India claims to be the most dominating player in the world market scenario.

\section{International scenario}

India is the single largest producer as well as consumer of cumin in the world accounting for about 70 per cent of world production followed by Syria 12 per cent, Iran 8 per cent, Turkey 6 per cent and other countries 4 per cent. The world market structure regarding cumin is very much concentrated as bulk production is performed by a fewer countries. Other countries that produce cumin seeds are
North Africa, China, United States of America, Indonesia, Sudan, Egypt, Morocco, Algeria and Libya.

\section{Export and import of cumin}

India is the largest producer of cumin seed but the country consumes most part of its produce and the rest is exported. Our country is the primary exporter of cumin seeds and cumin oil in the world. Its produce commands premium prices in the global markets due to its quality and flavor. India exported around 119 thousand tonnes of cumin seed during 201617. Also, the by-products of cumin seeds like oleoresins of cumin seeds and cumin oil is also exported from India. The exports of cumin from India are facing a stiff competition from the countries like Turkey and Iran as a bulk of their production is used for export purposes and also because these countries are able to provide the spice at much cheaper rates as compared to India. Even the production in Syria also affects the export prices and volume of cumin. The details of exports from India are presented in table 1.

India dominates in the world market with major export markets at Vietnam, USA, Bangladesh, UAE, UK and many other countries. The details of export of cumin from India to other countries are given in table 2.

India also exports cumin seed to Brazil, Spain, United Kingdom, Malaysia, Saudi Arabia and many other countries and cumin seed powder to Canada, UK and USA. India also exports oleoresins of cumin seed and cumin seed oil to USA, UK and Germany.

\section{Import}

Major importing countries of cumin in the global market are United States of America, Sri Lanka, United Kingdom, Netherlands, Japan and Brazil. India has the dominance in 
the major cumin consuming countries followed by Mexico, Portugal, Spain, Turkey, China, Japan, Netherlands, France and Morocco. Details of total import of cumin in India during 2012-13 to 2016-17 are shown in table 3 .

\section{Domestic scenario}

India is the largest producer and consumer of cumin seed in the world. The production of cumin in India hovers around 5.03 lakh tons during 2015-16 as it also has the maximum area granted to the cultivation of this spice. The country also has the largest area allotted towards cumin production i.e. around 8.08 lakh hectares during 2015-16. The level of production and the total area under cumin cultivation has increased significantly during the last few years. The area, production and yield of cumin in India are given in table 4 and its graphical representation is in figure 1.

Domestic production trends during 2007-08 to 2010-11 indicated that the yield increased steadily but moderated slightly during 201112. The average annual production has posted a significant increase during the past decade. Production has increased from approximately 170 thousand tonne in 2000 s to about 503 thousand tonnes in 2015-16.

In India, cumin seed is almost exclusively cultivated in Gujarat and Rajasthan. It grows abundantly in the mild, equable climate of Gujarat and Rajasthan where rich, well drained, sandy, loamy soil and the sunny, conducive environment are available. Thus
Gujarat and Rajasthan are the two main production centers in India. They contribute more than 99 per cent of total cumin production in the country. Gujarat is the largest producer of cumin seeds contributing about 60 per cent of the total production of India. Gujarat is largest cumin producing state in the country. It contributed around 2.8 lakh tons in the country's total produce in the year 2016-17 and the area under cumin cultivation was around 2.78 lakh hectares. The state wise details of area and production of cumin from 2012-13 to 2016-17 are shown in table 5.

Rajasthan is the second largest cumin seed producer in India. It is clear from the table 6 that area under cumin and production both increased in Rajasthan during period of 200607 to 2016-17. However, volatility is high in case of area as well as production in the state. The area under cumin cultivation was approximately 1.50 lakh hectares and production was 23760 tonnes respectively in 2006-07.The output of cumin declined sharply in Rajasthan due to poor climatic conditions.

However, area and production increased sharply thereafter with exception of year 2008-09 when production fell sharply on account of severe drought affecting the area and farmers shifting to other crops like guar and mustard fetching high price in comparison with cumin. The acreage and production is seen increasing at a steady pace thereafter with the increase in consumption domestically as well as internationally however the climatic conditions have remained a key factor to determine the overall output.

Table.1 Total export of cumin from India

\begin{tabular}{|c|c|c|c|c|c|c|c|c|c|}
\hline \multicolumn{2}{|c|}{$\mathbf{2 0 1 2 - 1 3}$} & \multicolumn{2}{c|}{$\mathbf{2 0 1 3 - 1 4}$} & \multicolumn{2}{c|}{$\mathbf{2 0 1 4 - 1 5}$} & \multicolumn{2}{c|}{$\mathbf{2 0 1 5 - 1 6}$} & \multicolumn{2}{c|}{$\mathbf{2 0 1 6 - 1 7}$} \\
\hline Quantity & Value & Quantity & Value & Quantity & Value & Quantity & Value & Quantity & Value \\
\hline $\mathbf{8 5 . 6 0}$ & 1153.1 & 121.50 & 1600.1 & 155.50 & 1838.2 & 97.79 & 1531.13 & 119.00 & 1963.20 \\
\hline
\end{tabular}

Source: Spice Board of India 
Table.2 India's top five export destinations for cumin

\begin{tabular}{|l|r|r|r|r|r|r|r|r|}
\hline \multirow{2}{*}{ Country } & \multicolumn{2}{|c|}{$\mathbf{2 0 1 3 - 1 4}$} & \multicolumn{2}{|c|}{$\mathbf{2 0 1 4 - 1 5}$} & \multicolumn{2}{c|}{$\mathbf{2 0 1 5 - 1 6}$} & \multicolumn{2}{|c|}{$\mathbf{2 0 1 6 - 1 7}$} \\
\cline { 2 - 11 } & Quantity & \multicolumn{1}{|c|}{ Value } & Quantity & \multicolumn{1}{|c|}{ Value } & \multicolumn{1}{|c|}{ Quantity } & \multicolumn{1}{|c|}{ Value } & Quantity & \multicolumn{1}{|c|}{ Value } \\
\hline VIETNAM & 38647.91 & 510.14 & 47823.04 & 535.42 & 24688.64 & 374.92 & 38872.6 & 653.33 \\
\hline U.S.A & 8116.94 & 126.05 & 11224.74 & 149.72 & 9776.26 & 179.64 & 11548.32 & 219.62 \\
\hline BANGLAD & 2086.00 & 24.46 & 2885.49 & 30.66 & 4274.95 & 54.28 & 10067.02 & 142.00 \\
ESH & & & & & & & & \\
\hline U.A.E & 11005.48 & 130.53 & 18692.91 & 224.00 & 5786.75 & 85.51 & 8577.04 & 133.99 \\
\hline U.K & 3340.41 & 54.29 & 3617.34 & 54.85 & 3756.8 & 73.24 & 3936.09 & 78.53 \\
\hline
\end{tabular}

Source: Spice Board of India

Table.3 Total import of cumin (black/ white) in India

(Quantity in tonnes, value in 'lakhs)

\begin{tabular}{|c|c|c|c|c|c|c|c|c|c|}
\hline \multicolumn{2}{|c|}{ 2012-13 } & \multicolumn{2}{|c|}{ 2013-14 } & \multicolumn{2}{|c|}{ 2014-15 } & \multicolumn{2}{|c|}{ 2015-16 } & \multicolumn{2}{|c|}{ 2016-17 } \\
\hline Quantity & Value & Quantity & Value & Quantity & Value & Quantity & Value & Quantity & Value \\
\hline 120 & 570.00 & 570 & 923.40 & 200 & 305.00 & 2000 & 3440.90 & 2800 & 4975.40 \\
\hline
\end{tabular}

Source: Spice Board of India

Table.4 Area, production and yield of cumin in India

\begin{tabular}{|c|c|c|c|}
\hline Year & Area ('000 Hectares) & Production ('000 MT) & Yield (kg/ha) \\
\hline $\mathbf{2 0 0 6 - 0 7}$ & 409.0 & 176.5 & 431 \\
\hline $\mathbf{2 0 0 7 - 0 8}$ & 420.8 & 166.5 & 395 \\
\hline $\mathbf{2 0 0 8 - 0 9}$ & 527.1 & 283.0 & 536 \\
\hline $\mathbf{2 0 0 9 - 1 0}$ & 517.1 & 303.9 & 587 \\
\hline $\mathbf{2 0 1 0 - 1 1}$ & 625.1 & 473.0 & 756 \\
\hline $\mathbf{2 0 1 1 - 1 2}$ & 843.4 & 462.6 & 548 \\
\hline $\mathbf{2 0 1 2 - 1 3}$ & 594.0 & 394.3 & 663 \\
\hline $\mathbf{2 0 1 3 - 1 4}$ & 690.1 & 445.0 & 644 \\
\hline $\mathbf{2 0 1 4 - 1 5}$ & 701.6 & 372.3 & 530 \\
\hline $\mathbf{2 0 1 5 - 1 6}$ & 808.2 & 503.3 & 623 \\
\hline $\mathbf{2 0 1 6 - 1 7}$ & 760.1 & 485.5 & 639 \\
\hline
\end{tabular}

Source: www.indiastat.com and Spice Board of India

Table.5 Major state wise area and production of cumin

(Area in '000 hectare, production in '000 tonnes)

\begin{tabular}{|l|c|c|c|c|c|c|c|c|c|c|}
\hline \multirow{2}{*}{ Major State } & \multicolumn{2}{|c|}{$\mathbf{2 0 1 2 - 1 3}$} & \multicolumn{2}{c|}{$\mathbf{2 0 1 3 - 1 4}$} & \multicolumn{2}{c|}{$\mathbf{2 0 1 4 - 1 5}$} & \multicolumn{2}{c|}{$\mathbf{2 0 1 5 - 1 6}$} & \multicolumn{2}{c|}{$\mathbf{2 0 1 6 - 1 7}$} \\
\cline { 2 - 13 } & Area & Production & Area & Production & Area & Production & Area & Production & Area & Production \\
\hline Gujarat & 373.90 & 283.30 & 370.00 & 280.00 & 266.70 & 251.43 & 295.40 & 300.94 & 278.70 & 284.00 \\
\hline Rajasthan & 220.00 & 111.00 & 320.08 & 165.03 & 434.78 & 120.83 & 511.08 & 200.85 & 479.67 & 200.00 \\
\hline $\begin{array}{l}\text { Total } \\
\text { including } \\
\text { others }\end{array}$ & 593.98 & 394.33 & 690.08 & 445.03 & 701.56 & 372.29 & 808.23 & 503.26 & 760.13 & 485.48 \\
\hline
\end{tabular}

Source: Spice Board of India 
Table.6 Cumin production in Rajasthan

\begin{tabular}{|l|r|r|r|}
\hline Year & Area ('000 hectares) & Production ('000 tonnes) & \multicolumn{1}{c|}{ Yield (kg/ha) } \\
\hline $\mathbf{2 0 0 6 - 0 7}$ & 149.69 & 23.76 & 159 \\
\hline $\mathbf{2 0 0 7 - 0 8}$ & 215.47 & 66.36 & 308 \\
\hline $\mathbf{2 0 0 8 - 0 9}$ & 169.14 & 42.73 & 253 \\
\hline $\mathbf{2 0 0 9 - 1 0}$ & 203.86 & 80.53 & 395 \\
\hline $\mathbf{2 0 1 0 - 1 1}$ & 330.64 & 114.93 & 348 \\
\hline $\mathbf{2 0 1 1 - 1 2}$ & 467.98 & 177.84 & 380 \\
\hline $\mathbf{2 0 1 2 - 1 3}$ & 495.69 & 176.36 & 356 \\
\hline $\mathbf{2 0 1 3 - 1 4}$ & 488.82 & 233.82 & 478 \\
\hline $\mathbf{2 0 1 4 - 1 5}$ & 434.78 & 120.83 & 278 \\
\hline $\mathbf{2 0 1 5 - 1 6}$ & 510.96 & 200.84 & 393 \\
\hline $\mathbf{2 0 1 6 - 1 7}$ & 500.14 & 206.94 & 414 \\
\hline
\end{tabular}

Source: Rajasthan Agricultural Statistics at a Glance, Directorate of Agriculture, Jaipur

Table.7 Leading cumin producing districts in Rajasthan

\begin{tabular}{|c|r|r|r|r|r|}
\hline \multicolumn{1}{|c|}{ Year } & Jodhpur & \multicolumn{1}{c|}{ Jalore } & \multicolumn{1}{c|}{ Barmer } & \multicolumn{1}{c|}{ Nagaur } & \multicolumn{1}{c|}{ Jaisalmer } \\
\hline $\mathbf{2 0 1 2 - 1 3}$ & 44663 & 41932 & 33635 & 25108 & 6589 \\
\hline $\mathbf{2 0 1 3 - 1 4}$ & 82533 & 40739 & 50009 & 30474 & 11024 \\
\hline $\mathbf{2 0 1 4 - 1 5}$ & 32453 & 34230 & 28415 & 11626 & 7815 \\
\hline $\mathbf{2 0 1 3 - 1 4}$ & 72107 & 34226 & 31840 & 31107 & 17817 \\
\hline $\mathbf{2 0 1 4 - 1 5}$ & 75405 & 34543 & 43115 & 22585 & 20240 \\
\hline
\end{tabular}

Source: Rajasthan Agricultural Statistics at a Glance, Directorate of Agriculture, Jaipur

Table.8 Traders' perception about factors responsible for price volatility in cumin

\begin{tabular}{|l|c|}
\hline \multicolumn{1}{|c|}{ Factors affecting price of Cumin } & Scores \\
\hline Higher domestic demand and export order & 4.84 \\
\hline Quality and grade affect its prices & 4.72 \\
\hline Weather & 4.72 \\
\hline Higher production affect prices & 4.68 \\
\hline Higher demand from processor, stockiest \& retailers increases price & 4.56 \\
\hline Futures' trading increase price & 4.44 \\
\hline Political Unrest in other countries & 4.16 \\
\hline Global production and prices affects price & 4.04 \\
\hline Carry Over Stock affect prices & 3.60 \\
\hline Speculators fluctuate prices & 3.24 \\
\hline Arbitration affects prices & 3.20 \\
\hline Increase/decrease in area affects prices & 3.20 \\
\hline EXIM Policies/ Trade Policy & 3.00 \\
\hline Commercial Stockholding increase price & 2.88 \\
\hline Arrival in market reduces prices & 2.68 \\
\hline Operation of middleman affect prices & 2.60 \\
\hline Price of substitute crop affects price & 2.00 \\
\hline Increase in production cost increase prices & 2.00 \\
\hline Population increases price & 1.68 \\
\hline Income growth of consumer increases price & 1.44 \\
\hline
\end{tabular}


Fig.1 Area, production and yield of cumin in India

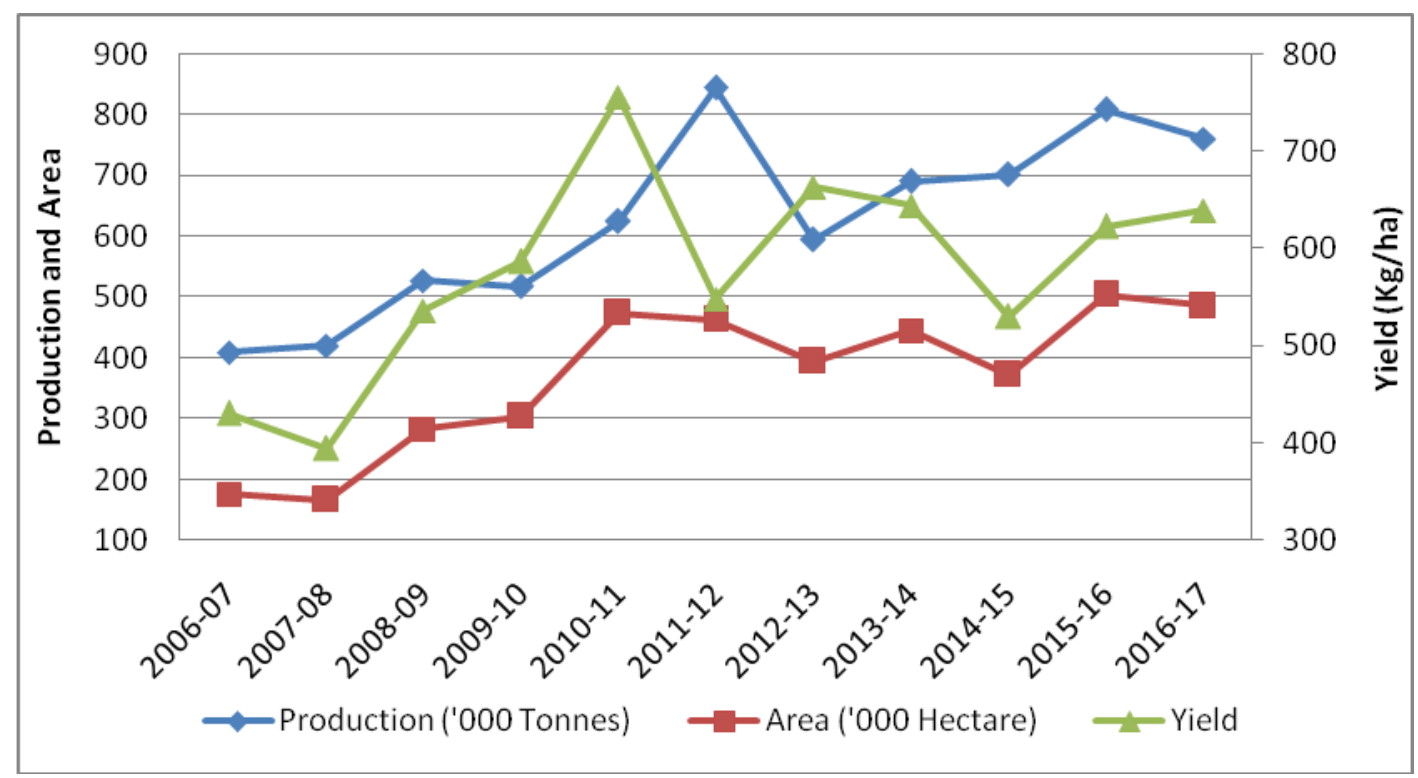

In Rajasthan state Jodhpur, Jalore, Barmer, Nagaur, Jaisalmer and Pali districts are the main producing districts. Detail from 2012-13 to 2016-17 of major producing districts of cumin are tabulated in table 7. The Nagaur mandi is the largest trading center for cumin seed in Rajasthan because now the cumin market has shifted from major producing areas viz, Jalore, Jaisalmer, Barmer etc. to Unjha at Gujarat. The price of cumin seed in Gujarat mandies is normally higher, therefore many farmers from Rajasthan market bring their produce in mandies of Gujarat. Besides this other factors for shifting of major cumin mandi from Rajasthan to the Gujarat mandies are cash payment, weight of commodity in front of farmers, lower market cess, availability of processors, exporters and brokers and better infrastructure facilities available for trading purpose.

\section{Factors affecting price of the cumin}

There are various factors responsible for affecting the prices of the cumin. A detailed survey of 50 traders was conducted in the Nagaur mandi to understand their views regarding major factors affecting the prices.
For this purpose response of the traders was recorded on 5 point likert scale. The detailed results of the survey are shown in table 8 . According to the traders' perception, higher domestic demand and export orders are the most important factors responsible for the price volatility because arrival of the commodity is only during the season in March-May while its consumption is spread throughout the year. In addition, the consumption is spread throughout the country, though the cultivation is from Gujarat and Rajasthan. So there is high demand of the cumin within our country as well as in the international market.

The other important factors according to the traders' perception are its quality and grade and because of its quality Indian cumin fetches premium prices not only in the domestic but also in the international market.

The prices display high volatility due to its seasonal nature. Weather at the production centres, pests and diseases have an influence on the production of cumin and hence it is also one of the major factors according to traders perception that affects the overall 
prices of the crop. Besides weather, the other factor that influences the prices is its output expectation. The higher or lower production affects cumin prices. Even the domestic demand expectation also influence the prices because the market is not perfectly organized and even higher demand from some processor, stockiest and retailers influences the prices of the crop.

The other influencing factor of price variation is trading in the futures market. Futures market also plays an important role for affecting price of the cumin. The large players control a major share of the market and therefore affect overall prices of the crop.

The political unrest in the other major exporting countries like Syria also affects the prices as it affects the global supply. Other important factor is the global production and their prices because India's export demand for cumin depends upon the production of the other major producers like Syria, Iran and Turkey. They affect our export demand and consequently the prices.

There is not much surplus production of cumin in world and thus crop failure in any of its major producing country, pressurize the prices. Cumin is mainly exported however the total quantity imported is very small and are mainly used in the oleoresin industries. So, cumin prices are also sensitive to international supply and demand.

Even the stocks available in the market have its affect on the overall process of the cumin. Other related factors that are affecting its prices are because of the speculators and arbitrators. Beside this the overall increase/ decrease in the area of the cumin crop also influence the prices of the cumin in the market. These are the major factors that are responsible for the price variation in the cumin crop.
According to traders' views, factors like commercial stock holding of the cumin, arrival in the market, operation of the middleman in the market, prices of the substitute crop, increase in production cost, population increase and income growth of consumer does not have any effects on the overall price increase of the cumin.

The traders survey concluded that higher export order; quality and grade affect its prices; weather; higher production affect prices; higher demand from processor, stockiest \& retailers; futures' trading; political unrest in other countries; global production and prices are the major factors that affects the prices of the cumin. However, carry over stock; speculators; arbitration; increase or decrease in area and EXIM Policies/ Trade Policy are some of the other factors responsible for price variations.

\section{References}

CRN India (n.d.) Analyzing the Indian Stock Market. Retrieved from http://www.crnindia.com/commodity/je era.html

Crop-wise Final Estimates of Area, Production and Yield of Various Principal Crop during 2016-17 (2017) Retrieved from http://www.agriculture.rajasthan.gov.in/ content/agriculture /en/AgricultureDepartment-dep/agriculturestatistics.html

Gallagher, P. (n.d.) Some long-run factors affecting prices. In Food commodities and policies. Retrieved from http://www.apec.org.au/docs/08_fcm_p g.pdf

Kumar, V. (2017) Cumin: Supply Chain Constraints and Prospects. In Rural Pulse. Retrieved from https://www.nabard.org/auth/writereadd ata/tender/0501180716Rural\%20Pulse 
\%20-\%20XXIII.pdf

Rajasthan Agricultural Statistics at a Glance,

Directorate of Agriculture, Jaipur (2016) Retrieved from http://www.agriculture.rajasthan.gov.in/ content/dam/agriculture/Agriculture $\% 2$ ODepartment/ecitizen/agriculturestatistics/agriculture_statistics_201516.pdf

Schnepf, R. (1999) Assessing agricultural commodity price variability. Agricultural Outlook. Retrieved from http://agris.fao.org/agrissearch/search.do?recordID= US201302946639

Spice Board of India (n.d.) Statistics. Retrieved from http://indianspices.com/sites/default/file s/Major-spic-wise-area-and-productionweb-2015.pdf

\section{How to cite this article:}

Priyanka Solanki. 2019. Overall Scenario and Assessment of the Factors for Price Volatility of Cumin in Rajasthan. Int.J.Curr.Microbiol.App.Sci. 8(07): 2537-2545. doi: https://doi.org/10.20546/ijcmas.2019.807.313 